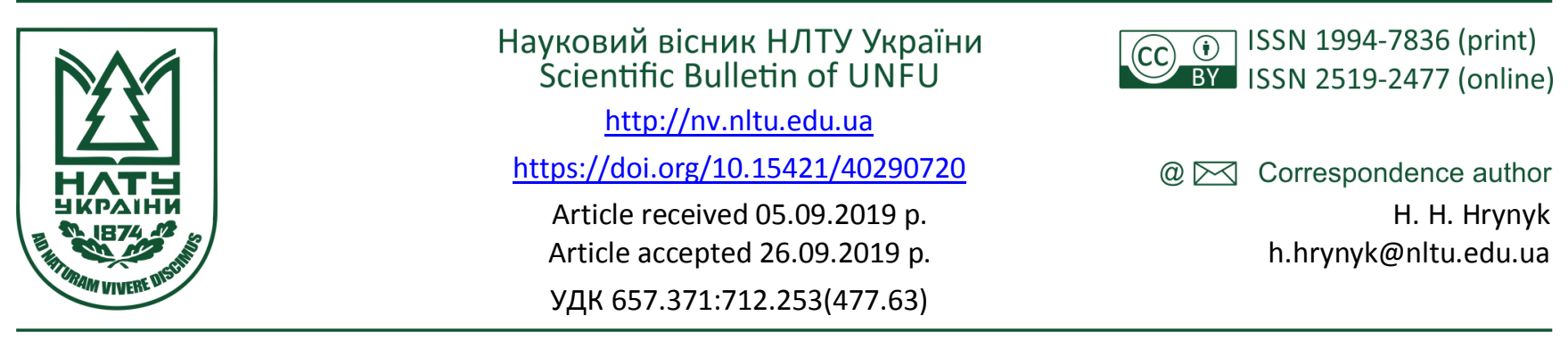

Ю. А. Мельник, Г. Г. Гриник, О. М. Гриник

Національний лісотехнічний університет Украӥни, м. Львів, Украӥна

\title{
ПІДСУМКИ ІНВЕНТАРИЗАЦІЇ ЗЕЛЕНИХ НАСАДЖЕНЬ ДЕНДРОПАРКУ "ПОДІЛЛЯ" МІСТА ХМЕЛЬНИЦЬКИЙ
}

\begin{abstract}
Наведено результати проведення інвентаризації зелених насаджень дендропарку "Поділля" міста Хмельницький, за якими встановлено видову (флористичну) структуру деревно-чагарникових рослин дендропарку, а також його загальний санітарний стан. Загалом на території дендропарку "Поділля" представлено 149 таксонів дерев і чагарників, відповідно - 3 відділу Покритонасінні 114, класу Хвойні - 35. Серед деревних рослин дендропарку "Поділля" найбільшу частку становлять такі види, як береза повисла, граб звичайний, липа дрібнолиста та ялина європейська. Важливим компонентом паркового насадження $\epsilon$ трав'яний ярус, який часто $є$ визначальним для формування середовища. За матеріалами ландшафтної таксації обліковано 38 видів трав'яних рослин. Окрім цього, визначено фітосанітарний стан зелених насаджень дендропарку, здійснено його зонування: виділено виділи та підвиділи, а також здійснено їх ландшафтну характеристику. За типом лісопаркового ландшафту серед виділених таксаційних ділянок переважає 34 виділи та підвиділи 3 типом ландшафту 1а, тобто у парку сформувалися переважно закриті повнотні насадження горизонтальної зімкнутості 0,6-1,0. Загалом рекреаційна оцінка паркових насаджень $є$ середня. Деякі компоненти потребують нескладних заходів з покращення умов відпочинку, пересування в окремих напрямках обмежене. Опрацьовано нові підходи щодо способів комплексного оцінювання ландшафтно-планувальної структури території.
\end{abstract}

Ключові слова: інвентаризація; деревно-чагарникова рослинність; оцінка стану насаджень; озеленення; благоустрій території.

Вступ. Одним з найважливіших чинників для створення повноцінної системи санітарно-гігієнічних, екологічних та мікрокліматичних умов для мешканців сучасних населених пунктів та для формування естетичного ландшафту є зелені насадження. Такі насадження $є$ чи не єдиним природним елементом, який не зазнав істотних змін. На жаль, площі, які займають зелені насадження, щорічно скорочуються переважно через необдуману чи нерегульовану людську діяльність. Внаслідок антропогенного впливу відбуваються зміни клімату та, відповідно, змінюється видовий і віковий склад міських насаджень. Зважаючи на те, що міські насадження $є$ натуральною адсорбентом летких полютантів та перешкодою для впливів шуму, електромагнітного випромінювання, пилу та решти негативних чинників, а також зменшують амплітуду температурних коливань та вологості повітря, покращують якість середовища, у якому живе людина, важливість зелених насаджень $є$ надзвичайно високою .

Історична довідка. Дендропарк "Поділля" - паркпам'ятка садово-паркового мистецтва місцевого значення в Україні. Пам'яткою садово-паркового мистецтва місцевого значення парк став відповідно до розпорядження голови виконкому обласної Ради депутатів трудящих від 22.10.1969 року № 358-р. Розташований у м. Хмельницькому, в мікрорайоні Виставка, на перехресті Проспекту Миру та Старокостянтинівського шосе (Yesunin, 2005; Yesyunin, 2008). Дендропарк належить до заповідного фонду Хмельницької області. Площа дендропарку становить 36,3 га. Фактично дендрологічний парк "Поділля" було закладено 1964 р. шляхом звезення саджанців з багатьох ботанічних садів України та 3 території розсадників (History of Proskurov, 2014; Dendropark "Podillya", 2014; Dudin et al., 2016). Екзоти часто вирощували з насіння, яке збирали на території інших парків. Колекція формувалася впродовж доволі тривалого часу та за літературними даними становила понад 420 таксонів. За даними Л. П. Казімірової (2006), тут представлено 12 форм та 174 види декоративних форм деревних рослин (Kazimirova, 2006).

Мета роботи - здійснити інвентаризацію та проаналізувати стан зелених насаджень дендропарку "Поділля" Хмельницького.

Методика інвентаризації насадження. Інвентари-

Інформація про авторів:

Мельник Юрій Анатолійович, канд. с.-г. наук, доцент, кафедра ботаніки, деревинознавства та недеревних ресурсів лісу. Email: yu.melnyk@nltu.edu.ua; https://orcid.org/0000-0003-3134-7915.

Гриник Георгій Георгійович, д-р с.-г. наук, ст. наук. співробітник, кафедра лісової таксації та лісовпорядкування. Email: h.hrynyk@nltu.edu.ua; https://orcid.org/0000-0001-7417-5047, ResearcherID: Q-8126-2017

Гриник Олена Миколаївна, канд. с.-г. наук, доцент, кафедра ботаніки, деревинознавства та недеревних ресурсів лісу. Email: o.hrynyk@nltu.edu.ua; https://orcid.org/0000-0002-2710-6118. ResearcherID: Q-8111-2017

Цитування за ДСтУ: Мельник Ю. А., Гриник Г. Г., Гриник О. М. Підсумки інвентаризації зелених насаджень дендропарку "Поділля" міста Хмельницький. Науковий вісник НлТУ України. 2019, т. 29, № 7. С. 101-107.

Citation APA: Melnyk, Yu. A., Hrynyk, H. H., \& Hrynyk, O. M. (2019). Results of the Inventory of Dendropark "Podillya" of Khmelnitsky City. Scientific Bulletin of UNFU, 29(7), 101-107. https://doi.org/10.15421/40290720 
зація зелених насаджень передбачала: визначення загальної площі дендропарку "Поділля", у тому числі зайнятої деревами, кущами, квітниками, газонами, стежками тощо; визначення кількості дерев і кущів за видами насаджень, породами, віком, діаметром на висоті 1,3 м стовбурів дерев та стану їхнього утримання (Andronov \& Bogdanov, 1974; Anuchin, 1982; Atamanyuk et al., 1987). Інвентаризаційний план виконано у масштабі 1:2000. Після виготовлення інвентаризаційного плану дендропарку "Поділля" проводили обчислення його площі. Обчислена загальна площа земельної ділянки не повинна відрізнятися від суми площ окремих ділянок більш ніж на 0,1%. Допустиму похибку розподіляли пропорційно до площі кожної складової частини. Територію дендропарку поділено на ділянки (виділи, підвиділи), які в натурі обмежуються доріжками, алеями чи іншими постійними елементами внутрішньої ситуації. Цим умовним ділянкам присвоювали порядкові номери (Anuchin, 1982; Instruction, 2007; Melnyk et al., 2009; Melnyk, Melnyk, 2011; Kendzora et al., 2013).

Якісний стан дерев насаджень визначали за такими ознаками та розподіляли на категорії: добрий - дерева здорові, нормально розвинуті, листя густе, рівномірно розміщене на гілках, листя чи хвоя нормального розміру і забарвлення, немає ознак хвороб і шкідників, ран, пошкоджень стовбура і скелетних гілок, а також дупел; задовільний - дерева здорові, але з ознаками вповільненого росту, з нерівномірно розвиненою кроною, на гілках мало листя, $є$ незначні механічні пошкодження і невеликі дупла; незадовільний - дерева дуже ослаблені, стовбури викривлені, крони слабо розвинені, є сухі та гілки, що засихають, приріст однорічних пагонів незначний, механічно пошкоджені стовбури, дупла. Стан кущів визначали за такими ознаками: добрий - кущі нормально розвинені, здорові, листя густе по всій висоті, сухих і гілок, що відмирають, немає, без механічних пошкоджень і пошкоджень через хвороби, забарвлення і розміри нормальні; задовільний - кущі здорові, з ознаками уповільненого росту, листя мало, є сухі гілки, крона одностороння, стебла частково оголені знизу, є незначні механічні пошкодження і пошкодження, заподіяні шкідниками; незадовільний - кущі ослаблені, перерослі, значно оголені знизу, листя дрібне, багато сухих гілок, механічних пошкоджень та пошкоджень, заподіяних шкідниками (Instruction, 2001).

Визначали три класи якості стану лісопаркових насаджень, а саме: 1-й клас - змішані багатоярусні насадження із зімкнутістю крон дерев 1-го ярусу в масивах, групах не нижче 0,7 (не враховуючи галявин) або чисті, невеликі (3-5 га) березняки, дубняки із зімкнутістю крон 0,4 і вище. Насадження здорові, життєздатні. Непошкоджена лісова підстилка охоплює не менше 80 \% площі. Окремі дерева, групи дерев розміщені нерівномірно. Галявини різних розмірів, мальовничої конфігурації з рівномірним трав'яним покровом, зручні для відпочинку. Меліоративних робіт не потребують. $\mathcal{C}$ впорядковані дороги; 2-й клас - насадження чисті, одноярусні, площею понад 3-5 га, або змішані із зімкнутістю крон 0,5-0,6, рівномірно розміщені на територіі. Мають ознаки уповільненого росту і розвитку, до $20 \%$ сухих гілок у кроні. Непошкоджена лісова підстилка становить 50-80 \% площі, територія забур'янена. Галявин мало, вони однотипні за формою і розмірами, недостатньо мальовничі, потребують незначної роботи для оздоров- лення насаджень і меліорації. Доріг недостатньо; 3-й клас - насадження чисті та змішані, перебувають на стадії розпаду, із зімкнутістю крон дерев 1-го ярусу 0,20,4, або складаються 3 малоцінних порід (осика, тополя) з більшою зімкнутістю. Дерева і групи дерев розміщені на території рівномірно. Кількість сухих гілок у кроні перевищує $20 \%$. Непошкоджена лісова підстилка становить менше ніж 50\%. Велика забур'яненість. Галявин немає або вони не пристосовані для відпочинку. Потребують значної роботи для оздоровлення насаджень, проведення санітарних заходів або значних за обсягом меліоративних робіт. Упорядковані дороги відсутні (Instruction, 2001; Instruction, 2007).

Результати дослідження. Ландшафтною таксацією територію денропарку "Поділля" поділено на ландшафтні виділи, у межах яких визначали основні таксаційні параметри дерев і кущів та ландшафтні характеристики насаджень (рисунок).

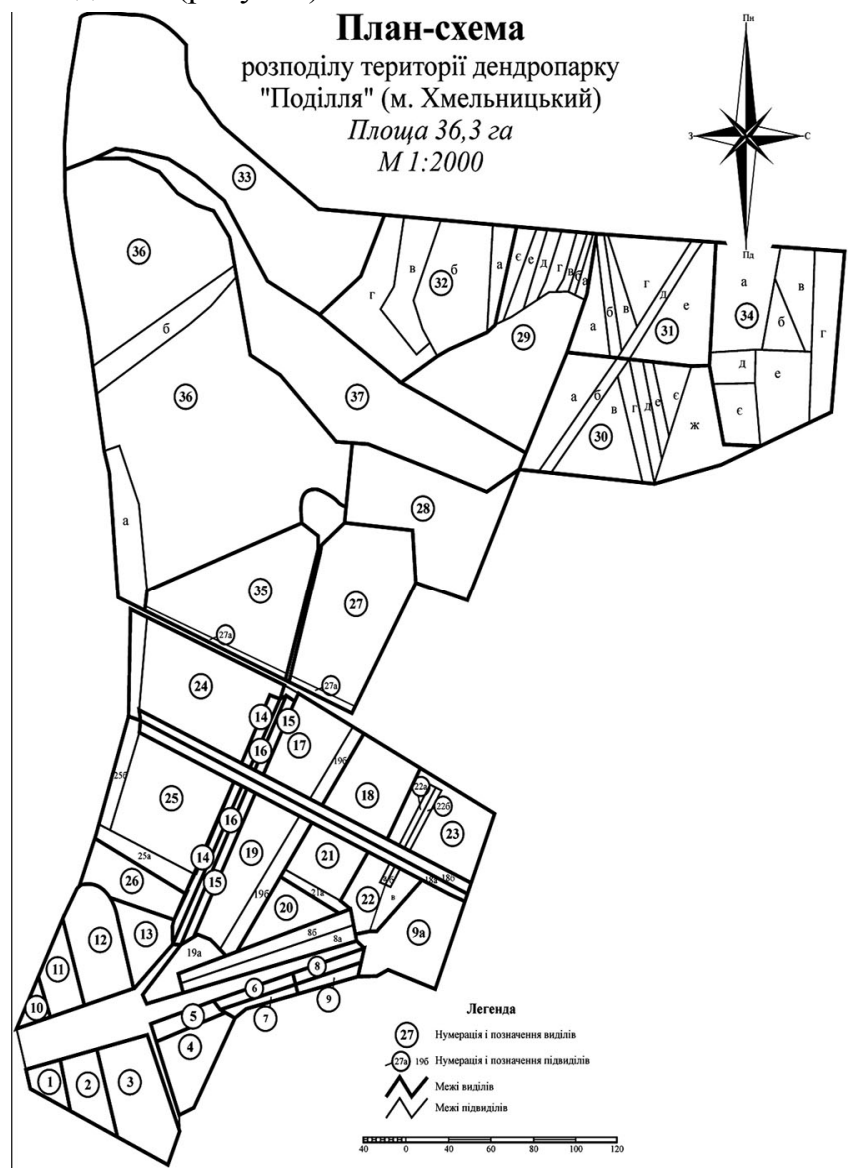

Рисунок. Розподіл території дендропарку на ландшафтні виділи та підвиділи

Дендропарк "Поділля" поділено на 37 ландшафтних виділів. За умови неоднорідності насаджень у межах виділів виділено підвиділи (загалом 80). Окрім цього, територію дендропарку умовно поділено на фасадну (нову) частину площею 12,2 га та лісопаркову частини, площею 24,1 га. Функціональне зонування території дендропарку передбачало виділення репрезентативновхідної зони, яка включає Меморіал Слави і представлена відкритими ландшафтами у вигляді квітників та газонів або в їх поєднанні. Спортивно-прогулянкова зона сформована вздовж велосипедної доріжки у старій частині у таких виділах. Господарська зона охоплює будиночок садівника та господарські приміщення поблизу нього і розташована у 23 виділі. Відпочинкова зона 3 
дитячим майданчиком і спортивними атракціонами розташована в центрі фасадної (нової) частину у 19 виділі (Melnyk et al., 2015).

Загалом на досліджуваній території дендропарку (площа 36,3 га) було обліковано 11729 дерев. Перелік українських і латинських назв таксонів класу Хвойні (Pinopsida) та відділу Покритонасінні Angiosperms (Magnoliophyta) дендропарку "Поділля" Хмельницького наводимо згідно із сучасними таксономічними класифікаціями та електронних баз регіональних флор (Melnyk et al., 2016; The Flora Europaea, 1976; The Flora Europaea, 2010; The Plant List, 2019; Melnyk \& Melnyk, 2011):

- Хвойні Gymnosperms (Pinopsida): Pinaceae (Abies alba Mill., A. concolor (Gordon) Lindl. ex Hildebr., $A$. nordmanniana (Steven) Spach, Larix decidua Mill., Picea abies (L.) H.Karst., P. glauca (Moench) Voss 'Coerulea', $P$. g. (Moench) Voss 'Nana', P. pungens Engelm., P. p. Engelm. 'Argentea'; Pinus nigra J. F. Arnold, P. strobus L., $P$. sylvestris L.; Pseudotsuga menziesii (Mirb.) Franko, P. $m$. var. glauca (Beissn.) Franko, P. m. var. viridis Franko; Tsuga canadensis (L.) Carrière); Cupressaceae (Chamaecyparis lawsoniana (A.Murray bis) Parl., Ch. pisifera (Siebold \& Zucc.) Endl. 'Plumosa', Ch. p. (Siebold \& Zucc.) Endl. 'Plumosa aurea', Ch. p. 'Squarrosa' (Siebold \& Zucc.) Endl.; Thuja plicata Donn ex D.Don, T. occidentalis L., T. o. L. 'Aurea', T. o. L. 'Columna', T. o. L. 'Fastigiata', T. o. L. 'Ericoides'); Juniperus communis L., J. c. L. 'Hibernica', J. chinensis L., J. sabina L., J. s. L. 'Variegata', J. virginiana L. 'Pyramidalis'); Taxaceae (Taxus baccata L., T. $b$. var. fastigiata (Lindl.) Loudon, T. b. L. 'Prostrata').

- Покритонасінні Angiosperms (Magnoliophyta): Adoxaceae (Sambucaceae, Viburnaceae): (Sambucus nigra L.; Viburnum lantana L., V. opulus L.); Anacardiaceae (Rhus typhina L.); Berberidaceae (Berberis aquifolium Pursh); Betulaceae (Alnus glutinosa (L.) Gaertn.; Betula dahurica Pall., B. obscura Kotula, B. papyrifera Marshall, B. pendula Roth; Carpinus betulus L.; Corylus avellana L., C. colurna L.); Bignoniaceae (Catalpa bignonioides Walter); Caprifoliaceae (Lonicera maackii (Rupr.) Maxim., L. tatarica L., L. xylosteum L.; Symphoricarpos albus (L.) S. F. Blake); Cercidiphyllaceae (Cercidiphyllum japonicum Siebold \& Zucc. ex J. J.Hoffm. \& J. H.Schult.bis); Cornaceae (Cornus alba L. (Swida alba (L.) Opiz), C. sanguinea L. (S. sanguinea (L.) Opiz); Elaeagnaceae (Elaeagnus rhamnoides (L.) A.Nelson); Fagaceae (Castanea sativa Mill.; Fagus sylvatica L.; Quercus castaneifolia C. A.Mey., Q. palustris Münchh., Q. robur L., Q. rubra L.); Grossulariaceae (Ribes uva-crispa L.); Hydrangeaceae (Deutzia scabra Thunb.; Philadelphus coronarius L., P. coronarius L. 'Plena'); Juglandaceae (Carya cordiformis (Wangenh.) K. Koch; Juglans ailanthifolia Carrière, J. cinerea L., J. mandshurica Maxim., J. nigra L., J. regia L.,); Leguminosae (Fabaceae) (Gleditsia triacanthos L.; Maackia amurensis Rupr.; Robinia pseudoacacia L., R. pseudoacacia L. 'Umbraculifera'; Styphnolobium japonicum (L.) Schott (Sophora japonica L.)); Magnoliaceae (Liriodendron tulipifera L.; Magnolia kobus DC.); Malvaceae (Tiliaceae) (Tilia cordata Mill., T. platyphyllos Scop., T. platyphyllos Scop. 'Laciniata'); Moraceae (Morus alba L.); Oleaceae (Forsythia intermedia Zab.; Fraxinus excelsior L., F. pennsylvanica Marshall; Ligustrum vulgare L.; Syringa josikaea J.Jacq. ex Rchb.f., S. vulgaris L.); Platanaceae (Platanus acerifolia (Aiton) Willd., P. occidentalis L.); Rham- naceae (Frangula dodonei Ard. (Frangula alnus Mill.); Rhamnus cathartica L.); Rosaceae (Amelanchier ovalis Medik.; Chaenomeles japonica (Thunb.) Lindl.; Cerasus avium (L.) Moench, C. vulgaris Mill.; Cotoneaster horizontalis Decne.; Crataegus monogyna Jacq., C. sanguinea Pall., C. submollis Sarg.; Malus mandshurica (Maxim.) Kom. ex Juz., M. sylvestris Mill.; Opulaster opulifolius (L.) Kuntze (Physocarpus opulifolius (L.) Maxim.); Padus avium var. avium; Prunus cerasifera Ehrh. (P. divaricata Ledeb.), P. domestica L., P. serotina Ehrh.; Pyrus communis L.; Rosa canina L., Rosa $\times$ rugosa Thunb.; Spiraea bumalda Burv.; Sorbaria sorbifolia (L.) A. Braun; Sorbus aucuparia L., S. intermedia (Ehrh.) Pers., S. hybrida L., S. torminalis (L.) Crantz); Rutaceae (Phellodendron amurense Rupr.); Salicaceae (Salix alba L., S. a. var. vitellina (L.) Stokes, S. caprea L., S. cinerea L., S. fragilis L.; Populus nigra L., P. nigra L. 'Fastigiata', P. tremula L.); Sapindaceae (Aceraceae, Hippocastanaceae) (Acer campestre L., A. negundo L., A. platanoides L., A. platanoides L. 'Globosum', A. platanoides L. 'Lorbergii', A. pseudoplatanus L., A. pseudoplatanus L. 'Purpurea', A. saccharinum L., A. tataricum L., A. t. subsp. ginnala (Maxim.) Wesm.; Koelreuteria paniculata Laxm.; Aesculus $\times$ hybrida DC., A. flava Sol., A. hippocastanum L.); Scrophulariaceae (Buddlejaceae) (Buddleja davidii Franch.); Simaroubaceae (Ailanthus altissima (Mill.) Swingle); Ulmaceae (Celtis occidentalis L.; Ulmus glabra Huds., U. laevis Pall., U. minor Mill., U. pumila L.); Vitaceae (Parthenocissus quinquefolia (L.) Planch.).

Загалом на території дендропарку "Поділля" представлено 149 таксонів дерев і чагарників, відповідно - 3 відділу Покритонасінні 114, класу Хвойні - 35. Серед деревних рослин дендропарку "Поділля" найбільшу частку становлять такі види, як береза повисла (9 \%), граб звичайний (10\%), липа дрібнолиста (14\%) та ялина європейська (10\%). За результатами санітарної оцінки деревостану рекомендуємо вирубати 161 дерево, які переважно є сухостійними або перебувають на грані відмирання (Melnyk et al., 2015).

У підлісковому ярусі паркового деревостану ростуть такі чагарники, як: бузина чорна, бузки звичайний та угорський, жимолость звичайна, крушина ламка, ліщина звичайна, пухироплідник калинолистий, свидини біла та криваво-червона, ожина, садовий жасмин звичайний. Досить поширений дівочий виноград п'ятилистий - як грунтопокривна рослина та на деревах. Інші види представлені поодинокими екземплярами, однак формують досить щільний піднаметовий ярус (Kurchyevy et al., 2001; Kendzora et al., 2013; Mozol \& Hrynyk, 2017; Kysliuk et al., 2017).

Важливим компонентом паркового насадження $\epsilon$ трав'яний ярус, який подекуди є визначальним у формуванні середовища (Hrynyk \& Horbenko, 2011). За матеріалами ландшафтної таксації обліковано 38 видів трав'яних рослин: Apiaceae (Aegopodium podagraria L.); Aristolochiaceae (Asarum europaeum L.); Brassicaceae (Alliaria petiolata (M. Bieb.) Cavara and Grande); Caryophyllaceae (Stellaria media (L.) Vill.); Compositae (Asteraceae) (Achillea millefolium L., Arctium lappa L., Bidens tripartita L., Taraxacum officinale Webb); Cyperaceae (Carex hirta L., C. sylvatica Huds.); Dryopteridaceae (Dryopteris filix-mas (L.) Schott); Geraniaceae (Geranium sylvaticum L.); Lamiaceae (Ajuga reptans L., Glechoma hederacea L.); Leguminosae (Fabaceae) (Trifolium praten- 
se L.); Oxalidaceae (Oxalis acetosella L.); Papaveraceae (Chelidonium majus L.); Plantaginaceae (Scrophulariaceae) (Plantago lanceolata L., P. major L., Veronica officinalis L.); Poaceae (Agrostis capillaris L., Arrhenatherum elatius (L.) Beauv. ex J. et C. Presl, Dactylis glomerata L., Festuca rubra L., Lolium perenne L.); Ranunculaceae (Ranunculus acris L.); Rosaceae (Agrimonia eupatoria L., Fragaria vesca L., Geum urbanum L., Rubus caesius L.); Rubiaceae (Galium aparine L.); Urticaceae (Urtica dioica L.); Violaceae (Viola odorata L.); Woodsiaceae (Athyriaceae) (Athyrium filix-femina (L.) Roth).

Найпоширенішими серед травостану є подорожник ланцетний, яглиця звичайна, щучка дерниста, розхідник європейський, осока лісова, грястиця збірна, вероніка лікарська, ожина сиза, лопух справжній, зірочник середній, череда трироздільна та інші. Наявність цих видів свідчить як про багатство грунту на території парку, так і про значні сильватизаційні процеси та синантропізацію трав'яного ярусу.

Окрім видової структури насаджень дендропарку "Поділля", на підставі зібраних даних можна подати ландшафтну характеристику насаджень (таблиця). Окремо за кожним таксаційним виділом оцінено такі основні ландшафтні показники: тип ландшафту, рекреаційна стійкість, стадія рекреаційної дигресії, клас прохідності, клас проглядності, рекреаційна оцінка. Результати аналізу виявилися такими.

За типом лісопаркового ландшафту серед виділених таксаційних ділянок переважає 34 виділи та підвиділи 3 типом ландшафту 1а. Це означає, що у парку переважно сформувалися закриті повнотні насадження горизонтальної зімкнутості 0,6-1,0. На незначних територіях сформовані закриті повнотні насадження вертикальної зімкнутості 0,6-1,0, а саме 5 виділів. Значною кількістю представлені напіввідкриті ландшафти 2а та 26 відповідно 21 та 11 виділів та підвиділів. Напіввідкриті рідинні насадження 2в, зімкнутістю 0,1-0,2 представлені 4 виділами. Відкриті ділянки з одиничними деревами 3а та без деревних рослин $3 б$ представлені відповідно 4 та 3 виділами.

Табл. 1. Ландшафтно-таксаційна характеристика насаджень дендропарку "Поділля"

\begin{tabular}{|c|c|c|c|c|c|c|c|c|c|c|c|c|c|}
\hline \multirow[b]{2}{*}{ 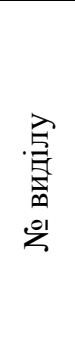 } & \multirow[b]{2}{*}{ 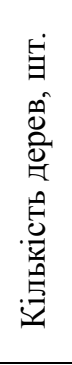 } & \multirow[b]{2}{*}{ Склад деревостану } & \multirow[b]{2}{*}{ 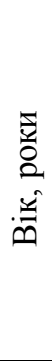 } & \multirow[b]{2}{*}{ 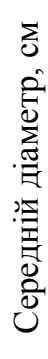 } & \multirow[b]{2}{*}{ 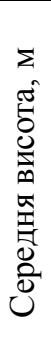 } & \multirow[b]{2}{*}{ 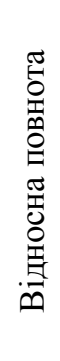 } & \multicolumn{7}{|c|}{ Ландшафтна характеристика } \\
\hline & & & & & & & 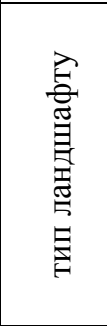 & 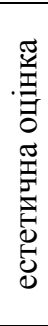 & 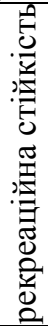 & 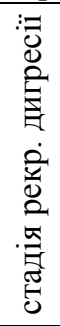 & 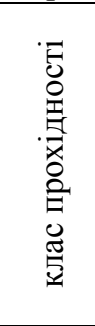 & 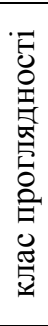 & 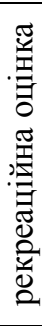 \\
\hline 1 & 2 & 3 & 4 & 5 & 6 & 7 & 8 & 9 & 10 & 11 & 12 & 13 & 14 \\
\hline 1 & - & - & - & - & - & - & 36 & $\mathrm{I}$ & - & - & добр. & 1 & - \\
\hline 2 & 15 & 8Ялє2Бп & 35 & 27 & 12 & 0,1 & $3 a$ & I & 2 & II & добр. & 1 & 2 \\
\hline 3 & 12 & 5Бп3Мдє2Ялє & 35 & 34 & 12 & 0,1 & $3 a$ & $\mathrm{I}$ & 2 & II & добр. & 1 & 2 \\
\hline 4 & 152 & 3Гз2Лпд1Клг1Гкз1Взш1Яз1Бп+Ялє, Тч,Тув & 40 & 49 & 13 & 0,9 & 26 & II & 2 & II & срд. & 2 & 2 \\
\hline 5 & 33 & 5Туз4Кпрг1Яоз & 30 & 14 & 9 & 0,2 & 26 & II & 2 & II & срд. & 2 & 2 \\
\hline 6 & 34 & 5Яз4Гкз1Лпд+Гз, Бп & 45 & 34 & 12 & 0,9 & 16 & II & 2 & III & срд. & 2 & 2 \\
\hline 7 & 58 & 5Гкз3Гз2Яз+Клс, Ос & 45 & 30 & 12 & 0,9 & 16 & II & 2 & III & срд. & 2 & 2 \\
\hline 8 & 76 & 4Гз2Бп2Ялє1Ос 1Гкз & 45 & 35 & 13 & 0,9 & 16 & II & 2 & III & срд. & 2 & 2 \\
\hline $8 \mathrm{a}$ & 268 & 4Гкз3Гз2Бп1Ос & 45 & 25 & 14 & 0,9 & 16 & II & 2 & II & добр. & 2 & 2 \\
\hline 9 & 86 & 4Гз2Гкз2Бп1Яз 1Лпд & 45 & 23 & 12 & 0,8 & 16 & II & 2 & III & срд. & 2 & 2 \\
\hline $9 \mathrm{a}$ & 109 & 3Ялє2Акб2Бп1Мдє1Яз1Чш & & 31 & 14 & 0,4 & $2 \mathrm{a}$ & II & 2 & III & пог. & 3 & 3 \\
\hline 10 & - & - & - & - & - & 0,0 & 36 & $\mathrm{I}$ & - & - & добр. & 1 & - \\
\hline 11 & 6 & 9Бп1Ялє & 35 & 47 & 11 & 0,1 & $3 a$ & I & 2 & II & добр. & 1 & 2 \\
\hline 12 & 47 & 3Гкз2Гхг2Бп2Тч 1Врб & 45 & 47 & 14 & 0,4 & 26 & II & 2 & III & срд. & 2 & 2 \\
\hline 13 & 52 & 4Бп2Лпд1Яз1Ялє 1Гз1Ос & 45 & 38 & 14 & 0,6 & 26 & II & 2 & III & срд. & 2 & 2 \\
\hline 14 & 53 & 10Яле & 45 & 39 & 12 & 0,9 & 26 & II & 2 & II & добр. & 1 & 2 \\
\hline 15 & 35 & 10Яле & 45 & 37 & 13 & 0,5 & $2 \mathrm{~B}$ & II & 2 & III & добр. & 1 & 2 \\
\hline 16 & 18 & 10 Клг & 25 & 22 & 5 & 0,1 & $2 \mathrm{~B}$ & II & 2 & III & добр. & 1 & 2 \\
\hline 17 & 152 & 3Ялє2Клг2Яз1Дгл1Лпш1Сч+Сз,Сфя & 45 & 27 & 15 & 0,6 & 26 & II & 2 & II & срд. & 2 & 2 \\
\hline 18 & 843 & 10Тув+Плк, Бт & 45 & 21 & 12 & 0,9 & $1 \mathrm{a}$ & $\mathrm{I}$ & 2 & III & добр. & 3 & 2 \\
\hline $18 \mathrm{a}$ & 76 & 10Лпд+Бп & 45 & 40 & 18 & 0,8 & $2 \mathrm{a}$ & II & 2 & II & добр. & 1 & 2 \\
\hline 186 & 74 & 10Лпд & 45 & 40 & 18 & 0,8 & $2 \mathrm{a}$ & II & 2 & II & добр. & 1 & 2 \\
\hline 19 & 123 & 6Лпд2Бп1Акб1Плк+Ялє, Чш, Ос & 45 & 30 & 16 & 0,4 & $2 \mathrm{~B}$ & $\mathrm{I}$ & 1 & II & добр. & 1 & 1 \\
\hline $19 \mathrm{a}$ & 66 & 6Лпд2Гз1Бп1Чш+ Гхг & 45 & 32 & 17 & 0,8 & $26+3 a$ & II & 2 & II & срд. & 2 & 2 \\
\hline 196 & 69 & 10 Бп+Чш & 45 & 44 & 20 & 1,4 & $2 \mathrm{a}$ & II & 2 & II & добр. & 1 & 2 \\
\hline 20 & 70 & 7Бп2Лпд1Ос & 45 & 29 & 19 & 0,5 & 26 & II & 2 & II & срд. & 2 & 2 \\
\hline 21 & 278 & 3Бп3Мдє2Сз2Лпд+Дгл, Ялє & 45 & 29 & 20 & 0,8 & $2 \mathrm{a}$ & II & 2 & III & срд. & 2 & 2 \\
\hline $21 \mathrm{a}$ & 13 & $10 \Gamma \times \Gamma$ & 45 & 31 & 9 & 0,4 & $2 \mathrm{a}$ & II & 2 & II & добр. & 2 & 2 \\
\hline 22 & 78 & 5Бп3Бпап2Бт+Акб, Анв & 45 & 27 & 19 & 0,6 & $2 a$ & II & 2 & III & добр. & 2 & 2 \\
\hline $22 \mathrm{a}$ & 18 & 10Мдє & 45 & 26 & 13 & 0,5 & $2 \mathrm{a}$ & II & 2 & II & срд. & 2 & 2 \\
\hline
\end{tabular}




\begin{tabular}{|c|c|c|c|c|c|c|c|c|c|c|c|c|c|}
\hline 1 & 2 & 3 & 4 & 5 & 6 & 7 & 8 & 9 & 10 & 11 & 12 & & \\
\hline 226 & 24 & 10Мде & 45 & 29 & 14 & 0,9 & $2 \mathrm{a}$ & II & 2 & II & срд. & 2 & 2 \\
\hline 22 в & 58 & 6Яв4Япс & 45 & 24 & 14 & 0,8 & $2 \mathrm{a}$ & II & 2 & II & срд. & 3 & 2 \\
\hline 23 & 180 & 2Дч3Клпр2Кат2Глз1Лпд & 45 & 25 & 14 & 0,5 & 26 & II & 2 & III & срд. & 3 & 2 \\
\hline 24 & 186 & 4Ялє1Акб1Клс1Яз1Кля1Кші1Крс & 45 & 28 & 12 & 0,3 & 26 & II & 2 & II & срд. & 2 & 2 \\
\hline 25 & 279 & 4Мдє2Ялє3Тув 1Кля & 45 & 20 & 11 & 0,3 & 26 & II & 2 & II & добр. & 1 & 2 \\
\hline $25 \mathrm{a}$ & 22 & 9Лпд1Гкз & 45 & 51 & 12 & 0,8 & $2 \mathrm{a}$ & II & 2 & II & добр. & 1 & 2 \\
\hline 256 & 44 & 9Тч1Глз & 45 & 51 & 18 & 0,9 & $2 \mathrm{a}$ & II & 2 & II & добр. & 1 & 2 \\
\hline 26 & 32 & 8Тч2Бп+Оc & 45 & 33 & 12 & 0,2 & $2 \mathrm{~B}$ & II & 2 & II & добр. & 1 & 2 \\
\hline 27 & 338 & 3Лпд3Бп2Яв1Клг1Яле & 45 & 36 & 18 & 0,7 & $2 \mathrm{a}$ & II & 1 & II & срд. & 2 & 1 \\
\hline $27 \mathrm{a}$ & 46 & 7ЯлєЗМдє+Бп & 45 & 39 & 14 & 0,8 & $2 \mathrm{a}$ & II & 2 & II & добр. & 1 & 2 \\
\hline 28 & 350 & 3Врб2Клг2Бп2Гхг1Чш+Ялє, Грз, Гз & 45 & 25 & 13 & 0,4 & $2 \mathrm{a}$ & II & 2 & II & срд. & 2 & 2 \\
\hline 29 & 503 & 4Яв3Клг2Лпд1Яс+Бха, Гхс & 45 & 30 & 16 & 0,8 & $1 \mathrm{a}$ & I & 1 & II & срд. & 2 & 2 \\
\hline $29 \mathrm{a}$ & 34 & $10 \Gamma$ кз & 45 & 22 & 12 & 0,8 & $1 \mathrm{a}$ & II & 1 & II & срд. & 2 & 2 \\
\hline 29 б & 48 & 10Акб & 45 & 21 & 10 & 1,3 & $1 \mathrm{a}$ & I & 1 & II & срд. & 2 & 2 \\
\hline 29 в & 45 & 10Яле & 45 & 22 & 11 & 0,9 & $1 \mathrm{a}$ & II & 1 & II & срд. & 2 & 2 \\
\hline 29 г & 49 & $10 \Gamma 3$ & 45 & 21 & 10 & 0,5 & 1a & II & 1 & II & срд. & 2 & 2 \\
\hline 29 д & 42 & 6Сз3Дз1Клг & 45 & 21 & 12 & 0,5 & $1 \mathrm{a}$ & II & 1 & II & срд. & 1 & 2 \\
\hline $29 \mathrm{e}$ & 44 & 10Яле & 45 & 28 & 15 & 0,7 & $1 \mathrm{a}$ & II & 1 & II & срд. & 2 & 2 \\
\hline $29 \epsilon$ & 54 & 10Клг & 45 & 24 & 13 & 0,6 & $1 \mathrm{a}$ & II & 1 & II & срд. & 2 & 2 \\
\hline $30 \mathrm{a}$ & 225 & 6Лпд4Гз & 45 & 20 & 10 & 0,5 & $1 \mathrm{a}$ & II & 1 & II & срд. & 2 & 1 \\
\hline 306 & 48 & 10Лпд & 45 & 24 & 12 & 0,5 & $1 \mathrm{a}$ & II & 1 & II & срд. & 2 & 1 \\
\hline 30 в & 270 & 10Клг & 45 & 21 & 11 & 0,6 & $1 \mathrm{a}$ & II & 1 & II & срд. & 2 & 1 \\
\hline 30 г & 51 & 10Лпд & 45 & 24 & 12 & 0,4 & $1 \mathrm{a}$ & II & 1 & II & срд. & 2 & 1 \\
\hline 30 д & 60 & 10Яле & 45 & 26 & 16 & 0,7 & $1 \mathrm{a}$ & II & 1 & II & срд. & 2 & 2 \\
\hline $30 \mathrm{e}$ & 36 & 10Кля & 45 & 22 & 10 & 0,4 & $1 \mathrm{a}$ & II & 1 & II & срд. & 3 & 1 \\
\hline $30 \epsilon$ & 58 & 10Лпд & 45 & 29 & 13 & 0,8 & $1 \mathrm{a}$ & II & 1 & II & срд. & 2 & 1 \\
\hline 30 ж & - & заболочене місце & - & - & - & - & 36 & III & - & - & пог. & 2 & 3 \\
\hline $31 \mathrm{a}$ & 65 & $10 \Gamma 3$ & 45 & 21 & 14 & 0,3 & $1 \mathrm{a}$ & II & 1 & II & срд. & 2 & 1 \\
\hline 31 б & 62 & $10 \mathrm{M} д \epsilon$ & 45 & 25 & 16 & 0,7 & $1 \mathrm{a}$ & II & 1 & II & срд. & 2 & 1 \\
\hline 31 в & 45 & 10Яле & 45 & 24 & 12 & 0,5 & $1 \mathrm{a}$ & II & 1 & II & срд. & 2 & 1 \\
\hline 31 г & 236 & $10 \mathrm{C} 3$ & 45 & 24 & 15 & 0,9 & $1 \mathrm{a}$ & II & 1 & II & срд. & 2 & 1 \\
\hline 31 д & 40 & 10Лпд & 45 & 21 & 12 & 0,3 & $1 \mathrm{a}$ & II & 1 & II & срд. & 2 & 1 \\
\hline $31 \mathrm{e}$ & 154 & 10Бп & 45 & 27 & 17 & 0,5 & $1 \mathrm{a}$ & II & 1 & II & срд. & 2 & 1 \\
\hline $32 \mathrm{a}$ & 29 & 10Ялє & 45 & 33 & 20 & 0,5 & $1 \mathrm{a}$ & I & 1 & I & пог. & 3 & 2 \\
\hline 32 б & 156 & 10Лпд & 45 & 30 & 19 & 0,4 & $1 \mathrm{a}$ & I & 1 & I & пог. & 3 & 2 \\
\hline 32 в & 66 & 10Бп & 45 & 28 & 17 & 0,3 & $1 \mathrm{a}$ & I & 1 & I & пог. & 3 & 2 \\
\hline 32 г & 86 & 10Влч & 45 & 44 & 22 & 0,6 & $1 \mathrm{a}$ & I & 1 & I & пог. & 3 & 2 \\
\hline 33 & 1005 & 3Влч2Бп1Гз1Лпд 1Клп1Ос1Тч & 45 & 23 & 16 & 0,4 & $2 \mathrm{a}$ & III & 1 & I & пог. & 3 & 3 \\
\hline $34 \mathrm{a}$ & 156 & 10 Бп & 45 & 21 & 14 & 0,3 & $1 \mathrm{a}$ & II & 1 & II & срд. & 2 & 2 \\
\hline 34 б & 52 & 10Яле & 45 & 29 & 18 & 0,7 & $1 \mathrm{a}$ & II & 1 & II & срд. & 2 & 2 \\
\hline 34 в & 98 & 10Мдє & 45 & 32 & 23 & 0,8 & $1 \mathrm{a}$ & II & 1 & II & срд. & 2 & 2 \\
\hline 34 г & 120 & 6 6ГхгЗГз1Гкз & 45 & 23 & 11 & 0,4 & $1 \mathrm{a}$ & II & 1 & II & срд. & 2 & 2 \\
\hline 34 д & 96 & 10Яле & 45 & 22 & 14 & 0,8 & $1 \mathrm{a}$ & II & 1 & II & срд. & 2 & 2 \\
\hline $34 \mathrm{e}$ & 332 & 10Яле & 45 & 20 & 11 & 0,7 & $1 \mathrm{a}$ & II & 1 & II & срд. & 2 & 2 \\
\hline $34 \epsilon$ & 126 & 8 Клг 2 Яв & 45 & 24 & 12 & 0,8 & $1 \mathrm{a}$ & II & 1 & II & срд. & 2 & 2 \\
\hline 35 & 357 & 2Яз2Лпд2Бп1Дч1Мдє1Ялє1Дз+Чш, Клг, Яв & 45 & 34 & 20 & 0,7 & $1 \mathrm{a}$ & II & 1 & II & добр. & 1 & 2 \\
\hline 36 & 1532 & 3Лпд2Яв1Глг1Бп 1Ялє1Яз1Гз+Дз, Дч, Акб & 45 & 37 & 22 & 0,8 & $2 \mathrm{a}$ & II & 2 & II & добр. & 1 & 2 \\
\hline $36 \mathrm{a}$ & 50 & 9Лпд1Бп+Гз & 45 & 53 & 22 & 0,9 & $2 \mathrm{a}$ & II & 1 & $\mathrm{I}$ & добр. & 1 & 2 \\
\hline 36 б & 46 & $10 \mathrm{Oc}$ & 45 & 38 & 22 & 0,4 & $2 \mathrm{a}$ & II & 1 & I & добр. & 1 & 2 \\
\hline 37 & 780 & 3Врл3Врб2Влч2Влс+Врк & 25 & 18 & 12 & 0,4 & $2 \mathrm{a}$ & III & 1 & $\mathrm{I}$ & пог. & 3 & 3 \\
\hline Всього & 11729 & & & & & & & & & & & & \\
\hline
\end{tabular}

За естетичною оцінкою виділів їх кількість розділилася в такий спосіб.

Так, I клас естетичної оцінки мають 28 виділів та підвиділів. Це підвищені, добре дреновані умови зростання, I-II класів бонітету. Проглядність і прохідність добрі; захаращеності і сухостою немає; різноманітне живе трав'яне вкриття; доступні для відпочинку і купання водойми; тип ландшафту відповідає запроектованому.
II клас мають 49 виділів та підвиділів, які характеризують слабодреновані вологі умови зростання III-IV класу бонітету. Проглядність і прохідність понижені; захаращеність і сухостій до $5 \mathrm{~m}^{3} /$ га; доцільно формувати інший тип ландшафту. На відкритих просторах трав'яний покрив однорідний, галявини - по зволожених місцях з горбкуватою поверхнею; необхідне планування поверхні; береги водойм низькі, але доступні; прилягаючі простори несприятливі для відпочинку. 
III клас мають 3 виділи, які займають понижені заболочені місця, IV-Va бонітету. Потребують осушення i корінної реконструкції насадження.

За шкалою рекреаційної стійкості насаджень 39 виділів і підвиділів віднесено до 1 класу. Насадження абсолютно здорові, доброго росту. Підріст, підлісок і живий надгрунтовий покрив доброї якості і повністю покривають грунт. Здорових дерев у хвойних насадженнях не менше 90, а в листяних - 70\%. Приблизно така сама кількість (38 виділів) має дещо гірші показники і віднесена до 2 класу рекреаційної стійкості.

Найбільша кількість насаджень знаходяться на II стадії рекреаційної дигресії. У таких насаджень трав'яний покрив мало порушений. Ярусність виражена. Бур'яни відсутні, проективне вкриття 50-70 \%. Поновлення задовільне і добре, наявний самосів ценозоутворювальних порід. Переважають дерева доброго і задовільного стану (75-90 \%). Ландшафтних ділянок, де підлісок і підріст відповідає умовам місцезростання (8 виділів) і це відповідає I стадії рекреаційної дигресії. Незначна кількість ландшафтних ділянок (13 виділів) знаходяться на III стадії рекреаційної дигресії. У таких насаджень трав'яний покрив пошкоджений. Кількість лісових і лісолучних трав зменшується. Збільшується майже до максимуму кількість бур'янових видів. Ярусність покриву ще зберігається. Проективне вкриття 30 $60 \%$. Збережений підріст мало диференційований, майже відсутній підріст ценозоутворювальних порід.

У насадженнях дендропарку переважають виділи (47 виділів), які мають середній клас прохідності, тобто пересування утруднене в деяких напрямках. Пересування зручне у всіх напрямках у 23 виділах. Однак 8 виділів мають погану прохідність, що свідчить про сильне розростання трав'яної та чагарникової рослинності, заболочення місцевості.

За ступенем проглядності переважають насадження 2 класу проглядності (47 виділів), які дозволяють оглядати паркову територію на відстані 21-40 м. Насадження 1 класу проглядності зосереджені у 22 виділах, а 3 класу - в 11. Загалом рекреаційна оцінка паркових насаджень $є$ середня. Такі ділянки мають добрі показники. Дкеякі компоненти потребують нескладних заходів 3 покращення умов відпочинку, пересування в окремих напрямках обмежено. Окрім наведених вище характеристик ландшафтної оцінки, у насадженнях дендропарку обстежено деревні рослини. Результатом цього обстеження є відведення окремих екземплярів у рубку, оскільки їх санітарний стан є незадовільним. В інвентаризаційній відомості наведено перелік цих дерев із вказанням номера виділу, назви виду та основних причин відведення в рубку.

Висновки. За результатами інвентаризації дендропарку "Поділля" поділено на 37 ландшафтних виділів. За умови неоднорідності насаджень у межах виділів виділено підвиділи (загалом 80). Окрім цього, територію дендропарку умовно поділено на фасадну (нову) частину площею 12,2 га та лісопаркову частини, площею 24,1 га.

На досліджуваній території дендропарку "Поділля" (площа 36,3 га) було обліковано 11729 дерев. Загалом на території дендропарку "Поділля" представлено 149 таксонів дерев і чагарників, відповідно - 3 відділу Покритонасінні 134, класу Хвойні - 35.

Серед деревних рослин дендропарку "Поділля" найбільшу частку становлять такі види, як липа дрібно- листа (14 \%), граб звичайний (10\%), ялина європейська (10\%) та береза повисла (9\%).

За результатами санітарної оцінки деревостану рекомендовано вирубати 161 дерево, які переважно є сухостійними або перебувають на межі відмирання.

У підлісковому ярусі паркового деревостану представлені такі кущі, як: бузина чорна, бузки звичайний та угорський, жимолость звичайна, крушина ламка, ліщина звичайна, пухироплідник калинолистий, свидини біла та криваво-червона, ожина, садовий жасмин звичайний. Загальна кількість кущів становить 46 видів.

За матеріалами ландшафтної таксації обліковано 38 видів трав'яних рослин. Найпоширенішими серед травостану $\epsilon$ подорожник ланцетний, яглиця звичайна, щучка дерниста, розхідник європейський, осока лісова, грястиця збірна, вероніка лікарська, ожина сиза, лопух справжній, зірочник середній, череда трироздільна та ін.

Основні ландшафтні показники (тип ландшафту, рекреаційна стійкість, стадія рекреаційної дигресії, клас прохідності, клас проглядності, рекреаційна оцінка) розподілено так:

- за типом лісопаркового ландшафту серед виділених таксаційних ділянок переважає 34 виділи та підвиділи 3 типом ландшафту 1а. Значною кількістю представлені напіввідкриті ландшафти 2а та 26 відповідно 21 та 11 виділів та підвиділів. Напіввідкриті рідинні насадження 2в представлені 4 виділами. Відкриті ділянки 3 одиничними деревами 3 а та без деревних рослин 36 представлені відповідно 4 та 3 виділами.

- за естетичною оцінкою виділів їх кількість розділилася так:

- I клас естетичної оцінки мають 28 виділів та підвиділів;

- II клас - 49 виділів та підвиділів;

- III клас - 3 виділи.

- за шкалою рекреаційної стійкості насаджень 39 виділів і підвиділів було віднесено до 1 класу, а 38 виділів мають дещо гірші показники і віднесені до 2 класу рекреаційної стійкості;

- найбільша кількість виділів знаходиться на II стадії рекреаційної дигресії;

- у насадженнях дендропарку переважають виділи (47 виділів), які мають середній клас прохідності;

- за ступенем проглядності переважають насадження 2 класу проглядності (47 виділів), насадження 1 класу проглядності зосереджені у 22 виділах, а 3 класу - в 11.

Загалом рекреаційна оцінка паркових насаджень $є$ середня.

Окрім наведених вище характеристик ландшафтної оцінки, у насадженнях дендропарку обстежено наявні деревні рослини. Результатом цього обстеження $є$ відведення деяких екземплярів у рубку, оскільки їх санітарний стан є незадовільним.

\section{Перелік використаних джерел}

Andronov, N. M., \& Bogdanov, P. L. (1974). Key to woody plants by leaves. Leningrad, 127 p. [In Russian].

Anuchin, N. P. (1982). Forest assessment. Moscow: Lesn. industry, 552 p. [In Russian].

Atamanyuk, Yu. A., Kostyuchenko, L. L., \& Ostapenko, Y. V. (1987). Reconstruction of urban green spaces. Kiev: Publishing house "Budivelnik", 240 p. [In Russian].

Dendropark "Podillya" (2014). Retrieved from: https://en.wikipedia.org/wiki/Dendropark_ "Podillya" (Khmelnitsky). [In Ukrainian].

Dudin, R. B., Melnyk, Yu. A., Hrynyk, H. H., Hrynyk, O. M., \& Melnyk, I. O. (2016). Inventory of green areas of Podillya arboretum in Khmelnytskyi. GDR Report. National Forestry University of Ukraine. DG No. 08.11-20-15, State registration number 0116U004043, Region. № 0216U002390. Lviv, 29 p. [In Ukrainian]. 
Flora Europaea. (2010). Volume 5. Alismataceae to Orchidaceae https://www.cambridge.org/ua/academic/subjects/lifesciences/botanical-reference/flora-europaea-volume5? format $=$ PB\&isbn $=9780521153706$

History of Proskurov. (2014). Retrieved from: http:/proskurov.info/component/content/article/70-streets/2732. [In Ukrainian].

Hrynyk, O. M., \& Horbenko, N. E (2011). Ecological characteristics of gas-forming herbaceous plants of the park zone of Lviv. Scientific Bulletin of UNFU, 21(9), 58-65. [In Ukrainian].

Instruction. (2001). Instruction on the inventory of green spaces in settlements of Ukraine (Approved by the Order of the State Committee for Construction, Architecture and Housing Policy of Ukraine No 226 of 24.12.2001). Retrieved from: http://zakon2. rada.gov.ua/laws/show/z0182-02/page. [In Ukrainian].

Instruction. (2007). Amendments to the Instruction on technical inventory of green spaces in cities and towns of urban type of Ukraine: Approved by the order of January 16, 2007, № 8 of the Ministry of Construction, Architecture and Housing and Communal Services of Ukraine. 18 p. [In Ukrainian].

Kazimirova, L. P. (2006). Parks-monuments of landscape art of Khmelnitsky region. Terra in-cognita Series: The Khmelnytsky Region. Kamianets-Podilskyi: PE Moshinsky V. S., 208-210. [In Ukrainian].

Kendzora, N. Z., Melnyk, Yu. A., Ivchenko, A. I., \& Hrynyk, O. M. (2013). Features of flowering representatives of the introduced dendroflora of the city of Lviv. Scientific Bulletin of UNFU, 23 (13), 31-37. [In Ukrainian].

Kendzora, N. Z., Melnyk, Yu. A., Ivchenko, A. I., \& Melnik, A. S. (2013). Peculiarities of vegetative shrubbery vegetation of the arboretum of the Botanical Garden of NLTU of Ukraine. Scientific Bulletin of UNFU, 23(2), 60-64. [In Ukrainian].

Kurchyevy, V. P., Ivchenko, A. I., Mazepa, M. I., Melnik, Yu. A., Proskurnitsky, V. M, \& Melnik, A. S. (2001). Dictionary of taxonomic names of woody plants (Ukrainian, Latin, Russian, English, German). Lviv: Swit, 2001. 148 p. [In Ukrainian].

Kysliuk, V., Kysliuk, V., Hrynyk, O., \& Hrynyk, H. (2017). Vegetative Propagation of Viburnum Opulus. Scientific Bulletin of UNFU, 27(1), 38-43. https://doi.org/10.15421/40270108
Melnyk, Yu. A., \& Melnyk, A. S. (2011). Coniferous trees are protected sites of Lviv. Scientific Bulletin of UNFU, 21(15), 17-21. [In Ukrainian].

Melnyk, Yu. A., Hrynyk, H. H., \& Melnyk, A. S. (2009). State of the dendroflora of the Levandivsky Park of Lviv. Scientific Bulletin of UNFU, 19(2), 53-59.

Melnyk, Yu. A., Hrynyk, H. H., Hrynyk, O. M., \& Melnyk, I. O. (2015). The current state of plantations of the Podillya arboretum in Khmelnitsky. Mater. 65th scientific-technical. conf. prof. composition, sciences. staff, doctoral students and aspirations on the basis of the sciences. activity in 2014, Lviv: EPD UNFU, 38-41. [In Ukrainian].

Melnyk, Yu. A., Hrynyk, H. H., Hrynyk, O. M., Shevchenko, S. M. (2016). Flora of vascular plants in the territory of the Podolia arboretum in Khmelnitsky. Mater. 66th scientific-technical. conf. prof. composition, sciences. staff, doctoral students and aspirations. on the basis of the sciences. activities in 2015. Lviv: EPD NLTU Ukraine, 79-83. [In Ukrainian].

Melnyk, Yu. A., Hrynyk, H. H., Melnyk, A. S., \& Hrynyk, O. M. (2018). Introduced tree species of vascular plants in the territory of the Podillya Arboretum in Khmelnitsky. Plant introduction in Volyn-Podillya: science, education, art of landscape formation, production: mater. Int. Research Practice Conf., (pp. 12-14), May 17-18. Ternopil. [In Ukrainian].

Mozol, O. V., \& Hrynyk, O. M. (2017). Some Prospects of the use and Reproduction of Weigela Species. Scientific Bulletin of UNFU, 27(10), 60-64. https://doi.org/10.15421/40271009

The Plant List. (2019). Retrieved from: http://www.theplantlist.org/1/ last accessed 2019/09/09.

The Flora Europaea. (1976). Volume 4. Plantaginaceae to Composite (and

https://www.cambridge.org/ua/academic/subjects/lifesciences/botanical-reference/flora-europaea-volume4? format $=$ HB\&isbn $=9780521087179$

Yesunin, S. (2005). Streets of Khmelnitsky. Ternopil, 122 p. [In Ukrainian].

Yesyunin, S. (2008). Walking Proskurov. Khmelnytsky, 180 p. [In Ukrainian].

Yu. A. Melnyk, H. H. Hrynyk, O. M. Hrynyk

Ukrainian National Forestry University, Lviv, Ukraine

\section{RESULTS OF THE INVENTORY OF DENDROPARK "PODILLYA" OF KHMELNITSKY CITY}

Historical Background. Dendropark "Podillya" is a park-monument of landscape art of local importance in Ukraine. The park became a monument of landscape art of local importance in accordance with the order of the Chairman of the Executive Council of the Regional Council of Workers' Deputies No. 358-p. The Purpose of the Work is to carry out an inventory and to analyze the condition of green plantations of the Khmelnytsky Poddillya arboretum. Planting Inventory Technique. The inventory of green space included: determination of the total area of the Dendropark "Podillya", including trees, shrubs, flower beds, lawns, trails, etc.; determination of the number of trees and shrubs by species of plantations, breeds, age, diameter at the height of $1.3 \mathrm{~m}$ of tree, trunks and their condition. The inventory plan was implemented on a scale of $1: 2000$. The qualitative status of the trees of the plantation was determined by appropriate characteristics and divided into categories. Three classes of quality of the state of forest plantations were determined. Research Results. By landscape assessment, the territory of the Dendropark "Podillya" is divided into landscape sections, within which the basic assessments parameters of trees and shrubs and the landscape characteristics of the plantations were determined. In total, 149 taxa of trees and shrubs are represented on the territory of Dendropark "Podillya", respectively - from the Angiosperms (Magnoliophyta) -114 , Pinopsida - 35. Among species of Dendropark "Podillya" are the species such as birch (9\%), common hornbeam $(10 \%)$, small leaf linden $(14 \%)$ and Norway spruce $(10 \%)$. An important component of park planting is the grassy layer, which is sometimes decisive in shaping the environment. According to landscape assessment, 38 species of herbaceous plants have been accounted. According to the type of forest park landscape among the selected assessment areas, 34 are identified and subdivided with the type of landscape 1a. In small territories, closed complete plantations of vertical closure of 0.6-1.0, namely 5 species, are formed. The semi-open landscapes $2 \mathrm{a}$ and $2 \mathrm{~b}$, respectively, of 21 and 11 subdivisions and subdivisions, are represented in large numbers. Semi-open liquid plantings $2 \mathrm{c}$, with a curvature of 0.1-0.2 are represented by 4 sections. Open areas with single trees $3 \mathrm{a}$ and without tree plants $3 \mathrm{~b}$ are represented by 4 and 3 sections, respectively. Conclusions. In general, the recreational assessment of parkland is average. In addition to the landscaping characteristics described above, arboreal plantations have been inspected for existing tree plants. The result of this examination is the removal of some specimens to the wheelhouse, as their sanitary condition is unsatisfactory. In total, 11729 trees were counted in the arboretum (36.3 ha area).

Keywords: inventory; tree and shrub plats; assessment of plantation status; landscaping; improvement of the territory. 